Marta Gregorčič

\title{
BOTTOM-UP STRATEGIES FOR COMMUNITY ENGAGEMENT AND INFORMAL LEARNING: TARGETING MEN AGED 60 YEARS OR MORE
}

\begin{abstract}
The article presents findings from a large-scale qualitative research study conducted as part of a threeyear Erasmus + project entitled Old Guys Say Yes to Community, which included partners from Slovenia, Portugal, Poland and Estonia. The project explored how inactive ageing affects the quality of life, health and well-being of men aged 60 years or more, and how (self-)exclusion from the community can lead to social and psychological 'death'. The article highlights four interconnected themes which are inadequately, insufficiently, or simply not addressed by national institutions and often also the non-governmental sector in the researched countries. The themes - the pluralisation of transitions to retirement and ageing; absent bodies and invisible lives; hegemonic masculinity and gendered experiences; and community-based learning, action and spaces - are supported by well-defined issues and obstacles preventing men from integrating into the community and are completed with suggestions and recommendations to implement much-needed changes. In addition to these four themes, the article touches upon a series of subtopics and questions that should be addressed by further scientific research in the observed countries.
\end{abstract}

Keywords: transitions to retirement, silver economy, productivity, hegemonic masculinity, gender identity, community-based learning and actions

\section{VKLJUČUJOČE STRATEGIJE ZA SKUPNOSTNO USTVARJANJE IN PRILOŽNOSTNO UČENIE PRI CILJNI SKUPINI MOŠKIH, STARIH 60 LET ALI VEČ - POVZETEK}

Članek predstavlja ugotovitve obsežne kvalitativne raziskave, ki je potekala v okviru triletnega projekta Erasmus+ Old Guys Say Yes to Community s partnerji iz Slovenije, Portugalske, Poljske in Estonije. $V$ projektu so bile proučevane posledice nedejavnega staranja moških, starih 60 let ali več, za kakovost njihovega življenja, zdravje in počutje, ki lahko vodijo tudi v (samo)izključevanje iz skupnosti ter s tem $v$ socialno in psihološko »smrt«. Članek osvetljuje štiri medsebojno povezane tematike, za katere je bilo ugotovljeno, da jih državne institucije v vključenih državah, pogosto pa tudi nevladni sektor, neustrezno

Marta Gregorčič, PhD, Faculty of Arts, University of Ljubljana, marta.gregorcic@ff.uni-lj.si 
ali nezadostno rešujejo, najpogosteje pa se z njimi sploh ne ukvarjajo. Tematike - pluralnost prehodov $v$ upokojitev in staranje; odsotna telesa in nevidna življenja; hegemonske moškosti in družbenospolne izkušnje ter na skupnosti temelječi učenje, prostori in početja - so podprte z natančno definiranimi problemi in ovirami za vključevanje moških v skupnost, hkrati pa dopolnjene s predlogi oziroma priporočili za prepotrebne spremembe. Članek poleg navedenih tematik nakaže tudi celo vrsto podtematik in vprašanj, ki bi jih bilo smiselno vključiti v nadaljnje znanstvene obravnave $v$ državah, ki so bile proučevane.

Ključne besede: prehodi v upokojitev, srebrna ekonomija, produktivnost, hegemonsko razumevanje moškosti, druženospolna identiteta, skupnostno učenje in početja

\section{INTRODUCTION}

The article presents selected findings of the project Old Guys Say Yes to Community, developed with European partners from Slovenia, Portugal, Poland and Estonia. Since September 2016, the project has been coordinated by the Faculty of Arts, University of Ljubljana, in collaboration with three partner universities and two non-governmental organisations dealing with the learning of older adults ${ }^{2}$. The aim of the research project was to find out how to improve the participation of older men aged 60 years or more in the local community and, in particular, how to encourage older men's socialisation, informal learning and inclusion in organisations which are not primarily meant for education and learning in the third and fourth life stages.

The background that drew the project partners to the research was the recognition that significantly fewer men in the third and fourth life stages than women of the same age realise the importance of lifelong learning and of the advantages of active participation in the community. The low participation rates of older men in organised learning programmes and other free-time activities are evident from a number of research studies (Merriam \& Kee, 2014; Schuller \& Desjardins, 2007; Tett \& Maclachlan, 2007), many of which link this to the men's quality of life, which is lower than the opportunities available to them and their environments otherwise allow (Courtenay, 2000; Golding 2011a, 2011b; Oliffe \& Han, 2014). Some researchers also demonstrate that older men marginalise, isolate and alienate themselves more frequently than their female partners (McGivney, 2004; Williamson, 2011; Vandervoort, 2012), that they are more likely to be subjected to loneliness in old age (Wang, Karp, Winblad \& Fratiglioni, 2002; Paúl \& Ribeiro, 2009), and that they increasingly rely on their wives and life partners, depending on them emotionally as well as in terms of care, etc. (Vandervoort, 2012; Dettinger \& Clarkberg, 2002).

1 Erasmus+, Strategic Partnership for Adult Education, agreement number: 16-KA204-021604, case number: KA2-AE-9/16.

2 The lead organisation was the University of Ljubljana; the partners organisations were the Slovenian Association of Adult Educators, the University of Algarve, the University of Wrocław, Tallinn University and the Association of Estonian Adult Educators - ANDRAS. 
Various statistical data also confirm that older men are less active than women. The largest discrepancies in women's favour when it comes to participation in active ageing community programmes in the countries monitored by Eurostat have been found in Sweden (14\%), Denmark (9.9\%), Finland (7.7\%), Iceland (7\%), Estonia (5.5\%) and France (4.9\%) (Eurostat, 2017). Although men are more active than women in Croatia, Germany, Turkey and Switzerland, the difference is practically negligible (between 0.2 and $0.6 \%$ ) (ibid.). It should be considered that besides cultural and religious aspects, these are gendered experiences, an aspect discussed further on in this article. The project partners came to similar conclusions in different national contexts: that the discrepancy in women's favour is even greater than seen in the statistics, and that men's participation in various organised active ageing and lifelong learning programmes is substantially more limited. For example, the average share of men in Activity Day Centres in Ljubljana or the Third Age University in Slovenia is $15 \%$. Adult Education Centres and Third Age Universities are similarly perceived as predominantly women's organisations managed by women.

According to the main findings of our research, this article discusses four less thematised issues that have been revealed through extensive research in all partner countries and which we believe emphasise the core themes that should be considered by local and national authorities as well as by civil society and NGOs dealing with active ageing, lifelong learning and the well-being of older adults. The identified themes are: a) The pluralisation of transitions to retirement and ageing; b) Absent bodies and invisible lives; c) Hegemonic masculinity and gendered experiences; and d) Community-based learning, action and spaces. The next section outlines the methodology of the study. The third section discusses all four themes with sub-topics and main problems or obstacles, while the forth section provides recommendations and suggestions for changes. The concluding section sums up the additional relevant findings from the project.

\section{THE METHODS AND THE SAMPLE}

As part of our project we undertook an extensive qualitative research study in 2017. Each partner country carried out three focus groups including representatives of NGOs and national institutions, ninety to one hundred semi-structured interviews with men aged 60 years or more, analyses of ten examples of good practice of the men's participation in their communities or elsewhere, analyses of national strategies and analyses of professional and scientific literature. The semi-structured interviews took an average of one hour and a half and they were, as a rule, conducted by qualified interviewers at the interviewees' homes, organisations they participate in or in 'safe spaces' where they felt comfortable. The interviews consisted of four sets of questions: (1) the interviewees' personal life histories; (2) their roles in the community and their understanding of the community; (3) an assessment and understanding of the lives of men aged 60 years or more in their communities; (4) their engagement with and participation in non-formal and informal organisations as well as the advantages in knowledge, skills, attitudes and practices they had gained in that way. 
To analyse the interviews, each partner chose the most appropriate qualitative content analysis and coding methods for their context and the realities revealed on the research field. In Slovenia the method of open coding and selective/focused coding (Glaser, 1978; 1992) was used. In Poland, Glaser (1992) as well as Schütze (2012) and Rosenthal (1993) were used. The qualitative content analysis of Schreir (2012) was used in Portugal, and Franzosi (2008) in Estonia. During the coding process and the first results, the partners discussed their findings, compared them and searched for similarities as well as differences. Due to diverse national and local contexts, educational and historical background, rich and diverse participants' life histories, etc., the partners gained very scattered results almost impossible to compare. Because of such a diverse research field and heterogeneous research data even within a partner country, we faced many difficulties to find coherent content analysis and results applicable for different communities (regions or country) presented in recommendation letters for local NGOs and local authorities in the researched countries. However, during the one-year process, each partner had many discussions with relevant stakeholders (civic society, local and national authorities, etc.), and finally common reflections brought us to common results, applicable also to other countries. However, there are four core themes highlighted in this article that appeared in each of the partner countries and which we believe deserve special attention in further research.

\section{FINDINGS}

\section{The pluralisation of transitions to retirement and ageing}

As revealed in our study, 'retirement is a break-even point' for older adults: the greater the importance of employment during the working period and the more time the seniors had devoted to it, the greater were the problems that arose with retirement, especially with no substitute activities. Forced retirement and intimidation with high taxation for post-retirement work were also very destructive for older adults and contributed to their inactivity in later life. The very 'start of retirement' meant a significant change for our interviewees especially in terms of 'time that remains and there is too much of' and 'time that now needs to be filled with something', and 'alternative activities' that have to be sought out. The change was most traumatic for those who faced it alone and those whose social networks had been built exclusively around their jobs.

In our societies it is expected that seniors stop their work activities on the day of retirement. It is a moment when they are permanently expelled from the labour market. They become 'receivers', 'a burden to society', 'non-active' members of society, requiring help and care, etc., perceived as a subordinate group. Facing ageing unprepared and alone increase vulnerability among older adults besides weakening the cognitive and cultural capital in the third and fourth life stages. Narratives pointed to the erasure of the men's past life histories: the work and activities of the men's working lives were lost or had ceased; some industries, professions, hobbies and other leisure activities have been dissolved, 
acquired a new function, or have ceased completely. They could no longer engage in some activities due to a decline in physical fitness and health. Many public places for meeting and socialising from the working lives of older men are gone, have either been privatised or appropriated by other generations. Furthermore, they proved that there is a lack of information about the possibilities open to them and the already existing activities and programmes in the community: it is often unclear how to access the dispersed information about opportunities for older adults.

In a quantitative research study of more than 2,000 interviewees (men and women) aged between 50 and 69 years from Germany, Schmidt-Hertha and Rees (2017) found that satisfaction with the workplace in all stages of the career, the positive perception of work and high personal identification with the workplace are crucial elements on the path to retirement or motivation for delaying retirement. Newly appearing practices of bridge employment (part-time work before retirement) and re-careering (a second career after legal retirement) (Boveda \& Metz, 2016) in some EU countries advocate new approaches regarding 'work vs. retirement'. Therefore, we believe that there are three subtopics that should be given more public, political and scientific attention in the future. The first is 'silver productivity and ageing', the second is 'post work lives and identities independent of paid work' and the third is 'ageing (men's) health-related behaviours', already highlighted by Peak and Gast (2014), with special attention given to the influence of the hegemonic masculinity framework over the life span, also discussed later in this article.

With these subtopics we tried to address the positive and gradual confrontation with the changes brought about by the third life stage. Such men can remain productive, take on (educational) mentorship, mediation, developmental and motivational roles in the company/organisation (transfer of practices, knowledge, experience, skills, competences), which bring them a sense of fulfilment and satisfaction. A further but new type of activity keeps them productive, agile, valued (important), and in fact supportive for the company, the industry, the business, the wider community, and their local environment. "Facing a pluralisation of transitions to the after-working phase of life, including different forms of intermediate stages, educational programs to design the transition and the stage of life after work, seems to be more relevant than ever" (Schmidt-Hertha \& Rees, 2017, p. 51). Besides, seniors need to develop identities independent of the paid work that occupied them their whole working life. As seen in the cases of community-based activity, particularly in community Men's Sheds developed in Australia (Carragher \& Golding, 2015; Golding, 2015; Mackenzie et al., 2017), such spaces allow "opportunities for regular, social interaction and hands-on activity in groups, within organizations and the wider community" (Golding, 2011a, p. 41). The value of this interaction is more than knowledge or skills-based; it is particularly powerful, therapeutic and likely to have broader wellbeing benefits when it is physical and social, involving other men and contributing to the organisation and the community (ibid.). 


\section{Absent bodies and invisible lives}

The transition from employment to retirement has changed significantly in the EU in the last decades. Not only are the years of service extending and the retirement age increasing, but pensions are also falling and they no longer guarantee a decent life (Schmidt-Hertha \& Rees, 2017). Retirement can be a breaking point in a variety of ways: psychologically, it is seen as a developmental task, as a longer-term process, or a critical life event (Filipp \& Olbrich, 1986). The loss of identifying activities points to the loss of self, the loss of worthwhile projects that reflected one's personality, and also the loss of the meaning of life (Wijngaarden, Leget \& Gossensen, 2015). Primarily it can mean a significant cut in people's biographies (Schmidt-Hertha \& Rees, 2017). Krajnc (2016) acknowledges that building a new meaning of life is a necessary preparation for a successful transition to retirement. Forcing older people into a social and psychological 'death' after retirement by not giving them the opportunity to fully experience the new life situation that they are entering can be devastating (Krajnc, 2016). The collective effort of the project partners was to call attention to men aged 60 or more, whose gendered experiences and social lives are different from women of their age as well as younger men. Our project identified nine complex obstacles/disadvantages showing the vulnerability of men in later life, which continue to be taboo issues in hegemonic masculinity discourse, and that often affect women as well.

First among them is 'becoming a nobody': solitude, (self-)isolation and (self-)marginalisation among older adults (particularly men) and the status/identity change have many consequences for health and well-being among older adults. Second, accessibility to quality services, adequate public infrastructure and mobility have become a major technical (and, above all, financial) obstacle for older adults with the degradation of the welfare and/or social state, which has a significant impact on their health and quality of life. Third, besides health issues and services (indicated by all partners), a number of other necessary services have become payable, while access to institutions and mobility in general is often inadequate. Special attention should also be paid to mental health and mental issues, underestimated and inadequately dealt with in all partner countries. Because of these problems, the men reported losing their independence and autonomy. Furthermore, poverty and financial distress as well as poorly managed home and social services were identified in all of the researched countries, as was the absence of adequate or sufficient social policies that would allow the community to be the centre of the resolution to the problems of older adults. Because the men have lost the position they used to have, they often do not know how to participate in an informal/non-formal environment where activities are led by women. Subsequently, discomfort was expressed from various perspectives concerning the spaces in which men are a minority, and recognition that men rarely approach (new) activities without the personal encouragement of their partners or important friends. Spaces for older adults are poorly marked, invisible and somehow hidden from community members. The interviewees showed a strong dependency on their life partners as companions and a strong emotional, social and informational reliance on them. They 
also stressed a strong need for political participation and active citizenship (particulary in the case of Slovenia, but not in Estonia). Last but not least, our study revealed (particularly in the case of Portugal) that men with a very low educational background find themselves in extremely limited and vulnerable situations in old age compared to those with a middle or higher level of educational background.

In view of all these obstacles and problems it is important to find out why in a number of countries, including Estonia, Poland, Portugal and Slovenia, older men have been, essentially speaking, excluded as relevant participants of society, because the consequences of their (self-)marginalisation and isolation can be dramatic. It is also important to find out why men aged 60 or more are perceived as absent and invisible in contemporary discourses (Fleming, 1999). Men's (self-)exclusion and inactivity in the third and fourth life stages have a significant impact on the quality of their lives, on cognitive and mental capital (Golding, 2011a, 2011b), on emotional well-being (Williamson, 2011) and, of course, most importantly, on their health (Courtenay, 2000; Golden, Conroy \& Lawlor, 2009; Mark \& Golding, 2012). Creating opportunities for participation in civic engagement in later life can have a significant impact on the social aspects of men's lives and health in general. In this regard two interconnected subtopics should be discussed and implemented in development strategies: particularly 'men's vulnerability in old age' (male suicide risk, depression, chronic illnesses and functional disabilities, financial difficulties, widowhood, solitude, etc.) (Canneto, 2015) and 'men's mental health' (masculinities and men's health, retirement-related depression and death) (Oliffe \& Han, 2014). Numerous social factors strongly influence health quality and well-being in old age as well.

\section{Hegemonic masculinity and gendered experiences}

The shorter life span of men is often presumed to be natural and inevitable; however, our research as well as prior studies (Courtenay, 2000) have found that men are more likely than women to adopt beliefs and behaviours that increase their health risks, and are less likely to engage in behaviours that are linked with health and longevity. Besides different behaviours and lifestyle, hegemonic masculinity and gender identity play an important role in ageing as well. "Gender capital may be an extremely useful concept for exploring men's and women's movement through occupational social spaces, and thus sheds light on the continuity and reproduction of occupational segregation" (Huppatz \& Goodwin, 2013, p. 294). Since the social construction of masculinities has garnered much attention in academic literature, more and more in-depth studies are emerging, arguing that masculinities are not easily defined (Mackenzie et al., 2017; Golding \& Foley, 2017) as gender practices shift under the influence of historical narratives as well as social, political and economic structures (Connell \& Messerschmidt, 2005; Creighton \& Oliffe, 2010), and that hegemonic masculinities are often represented by established stereotypes and structures that influence how men think and act in relation to their view of what 'being a man' means (Mackenzie et al., 2017).

Many scholars argue that masculinity is becoming more 'inclusive': more egalitarian, non-traditional and active in incorporating and adopting previously stereotypically 
feminine attributes, values, and practices (Anderson, 2009; Huppatz \& Goodwin, 2013). Others suggest that while these changes are apparent, they are not as extensive as some think and they have done little to alter structurally embedded gendered power relations and indeed might be happening as a way of maintaining these established relations within a neoliberal economic landscape (Bridges \& Pascoe, 2014; Mackenzie, et al., 2017). However, there are only few studies dealing with gendered experiences, gender capital and hegemonic masculinity in later life.

Besides the obstacles and problems already stated in prior sections that encompass gender issues, the project partners have found that older adults are mostly seen and treated as de-gendered. Gleibs et al. (2011) found out that gender imbalance and the de-emphasis on gender identities can have important implications for men's psychological well-being and the way they think about and perceive themselves. Barefoot at al. (2001) observed that men but not women showed an increase in non-somatic depression symptoms from age 60 onwards; they explained these results in terms of a shift in social roles and that the loss of social networks might be greater for men than for women. Our research revealed that older adults are treated as a homogenous group not only by care institutions or senior services but also by academics, the media, etc. Furthermore, activities for older adults mostly take place in age-segregated communities/places instead of in intergenerational community contexts. Unsuitable or inadequate existing activities (predominantly women's activities, themes, spaces, women participants, women's leadership) and the fragmentation of the institutions working with older adults often lead to men's withdrawal from the community to 'their safe spaces' (for example, to their pub) where they can foster hegemonic masculinities, etc. They become passive observers instead of active stakeholders in the community.

The findings in Slovenia showed that appropriate community places where men would be able to do 'their' activities - particularly connected with handwork and craft work - could work out in any community place, together with women's programmes, only if the place had a 'common' characteristic (open, autonomous, inclusive, suitable for encounters, discussions, co-working, socialising, etc.). The emphases were different in the other partner countries; however, the need for 'alternative programmes' was mostly due to social factors, especially poverty and low pensions that do not enable older adults to live decent lives, as well as proper/suitable community spaces that have vanished within the neoliberal landscape. The analyses of our research, particularly the collected examples of good practice, identify the advantages of men's clubs, men's sheds, men's spaces and activities, and even safe community houses/spaces for some groups of men, where they can socialise with each other (Reynolds et al., 2015), offering mutual support and where they can self-organise and redefine masculine capital to achieve older men's empowerment (Hanlon, 2012; Ribeiro, Paúl \& Nogueira, 2007; Carragher \& Golding, 2015). However, we estimated that men-only activities should be imposed only when other possibilities and options are inadequate for the specific local community. 


\section{Community-based learning, actions and spaces}

Unlike women, who participate in the most varied areas in public, private and family life, men's learning happens mostly in informal community spaces (Jelenc Krašovec \& Radovan, 2014). There are many reasons for men's non-participation in existing activities, among others, the dominant masculine capital that determines men's (self-)exclusion, their unwillingness to enter learning communities (classrooms, educational institutions) that are frequently feminised (Carragher \& Golding, 2015; Owens, 2000), the negative perception of their schooling in the past and/or low level of education (Mark \& Golding, 2012; McGivney, 1999, 2004), the weakening of cognitive and social capital, which is part of the ageing process and which affects men more than women (Merriam \& Kee, 2014; Schuller \& Desjardins, 2007; Tett \& Maclachlan, 2007), etc. The Old Guys interviewees' biographies revealed that the activities and lifestyle of the first two life stages determine the activities and lifestyle in the third and fourth life stages.

Besides the many obstacles and problems that allude to community learning and doing already identified in prior sections, there are also some paradoxes that occurred during the research. While talking about the engagement of older adults with the community, our interviewees expressed a strong desire to transfer their knowledge, skills, life stories, etc. They also did not want to be in a subordinate position or in a position of ignorance, or to be taught (especially by younger 'experts'), but wanted to transfer their knowledge and experiences to others, especially younger people, and craved such interactions. They also craved for political participation and decision-making processes (except in the case of Estonia). Another paradox is that older adults are often represented as a 'burden' in public discourse; much less they are portrayed as ,agents of progress' and respected for their invaluable contribution to the community, as revealed in the analyses of the project's focus groups. Their past and present contribution to the community is often neglected. The analyses also revealed that democratic and participatory processes are needed for the greater involvement of older adults in consultation and other practices that would enable them to contribute to the community that would not need to happen separately or segregated from the rest of the society.

Prior findings on the informal learning of older adults in participatory intergenerational community processes showed that (a) being a part of social action groups offers older adults an opportunity to learn about younger generations and their values; (b) for many older people, participation in the community constitutes an investment into future generations and offers them a sense of solidarity; (c) even if intergenerational cooperation and exchange is not a primary goal of community engagement, these dimensions have substantially and positively changed as a result of participation in mutual deliberation and actions between different generations; (d) collaborative decision making in mixed age groups led to an increased acceptance and tolerance by older and younger members; (e) the knowledge and skills that are necessary for social solidarity, intergenerational cooperation, awareness of others and social harmony increased most notably as a result of participation in the process of the self-organisation of citizens to enhance engagement in civic society (Jelenc Krašovec \& Gregorčič, 2017). 
Golding (2011a) demonstrates that social, local and situated learning can be the key for researchers and civil society to test ways of diminishing the levels of exclusion of the male population, while Reynolds et al. (2015) similarly recognised that male-oriented community programmes that embody similar characteristics to Men's Sheds have the potential to help men maintain meaningful connections to the activities and roles that they developed throughout their lifetime. As indicated by Fragoso et al. (2014), informal learning spaces are "crucial for the community to increase its level of organisation, to encourage participation, and to open doors so that adults can autonomously select those paths considered important for the future of the community or those activities that can have a positive effect on their lives." (p. 30) Drawing on two case studies in Malta, Formosa, Galen and Bonello (2014) came to similar findings as our project partners while searching for examples of good practices: that older men's learning occurs in avenues that are not customarily thought to be educational contexts (such as self-directed activities or learning projects, or as part of social institutions dealing with adult members or even learning connected to social movements) resulting in clear benefits for older men themselves and society in general.

\section{DISCUSSION: BOTTOM-UP STRATEGIES FOR COMMUNITY ENGAGEMENT AND INFORMAL LEARNING}

The Old Guys project found out that there were not any formal retirement preparation programmes in the researched countries. Therefore, programmes aiming to prepare seniors for old age and give meaning to old age should be developed and promoted within public institutions, trade unions and through NGOs. Such programmes are needed not only for older adults before retirement but in fact significantly earlier. Instead of forced and early retirement, laws should be drawn up to institutionalise gradual/partial retirement practices and a ,silver economy', and to encourage the economic integration of older adults. An inclusive longevity society could be developed through practices of old-new careers, involving older adults in mentoring, training, mediation, development, strategic, motivational, etc. roles/working groups/programmes in institutions and companies. Good examples of encouraging the positive perception of productivity and creativity could be done within public institutions and trade unions, for example. 'Partnerships' with older adults to activate a large spectrum of their untapped skills and rich experiences should be financially supported, and their work disseminated.

Research has shown that activities in the first two life stages decisively determine cognitive, social and cultural capital in the third and fourth life stages. Therefore, young people should also be informed and educated about the process of ageing and about old age (not only retirement). At the same time, this would encourage society in general (and not just older adults) to change the traditional and stereotypical views of old age and ageing. Our project also proved how older adults are mostly providers of wider development in the community through their volunteer, mutual and charity work (though mostly done by women), therefore national and local authorities must enable ways for older adults 
to transfer their knowledge, practices and skills to the wider population, strengthening intergenerational translation and exchange in cooperation with civic society and NGOs.

The need for corresponding public spaces could be seen throughout the men's narratives, which brings us to the suggestion that local authorities should evaluate the quantity and quality of public spaces. This evaluation should take into account the quality of access and transportation and their adequacy to promote different uses of the public spaces. Following this evaluation, local authorities can implement (short, medium or long-term) solutions to improve public spaces and create new ones. NGO representatives and other stakeholders in civic society can do their best to set up their own offices and reception rooms (or other facilities they are using) as safe spaces, community spaces, where people can come, meet, socialise and spend time together not as consumers but as community members.

Stakeholders in active ageing, lifelong learning and civil society in general will have to develop the sensitivity to recognise the causes and processes that have 'driven' older men out of public life in the community. Opportunities have mostly been seen a) in already existing and diverse educational and training programmes; b) in informing and raising awareness about them for older men; and c) in considering alternative activities for older men in their later life (Gregorčič, 2017). In some contexts of the Old Guys team, there is no lack of activities adequate for older men. In other contexts, there is an abundance of (formal or non-formal) activities that attract more women than men. But it is a fact that there is a lack of information about these opportunities. Furthermore, institutions in the same areas often offer activities without knowing what the other institutions are doing. Civil society institutions and local authorities should, therefore, better articulate the opportunities for a more active life, and work on the dissemination of these activities. A good example of a coordinated way of informing the public, a platform, etc., can be found in the Portuguese 'Golden Age' programme - Programa Idade D'Ouro. To promote a variety of activities so that both men and women have opportunities seems crucial.

The research has shown that older men highly value the independence and autonomy that defined them in their working life. The specific obstacles that prevent older adults from having adequate access and mobility in local environments should be identified, as should the possibilities for cheaper or free services for older adults in the context of the decentralisation of services, which should be enabled by the national government with the cooperation of civic society and local authorities. Programmes on cognitive ageing, (men's) mental health promotion, etc. should be developed and broader public discussions should be organised on these persisting taboo themes. National governments need to introduce long-term measures to improve the healthcare system and services to provide equal access for all people (including older adults). Besides non-profitable innovations towards 'opening' institutions for older adults, community co-management should also be developed, practising de-institutionalisation and community work.

Additionally, local communities should develop more democratic and participatory processes for the involvement of older adults in consultation and other practices that would 
enable them to contribute to the community. The personal approach has been shown to be the most effective - men being encouraged to participate or brought along to activities by their partners or friends. It's also important that they are addressed through 'activity', 'doing things', since (intergenerational or any other) cooperation can only be developed by 'doing' and not by 'spectating', as well as by various institutions and especially by NGOs and organisations focused on older adults. Our research outlined the pricelessness and importance of a wife/partner for older men in this life stage. This is why wives (or life partners) can probably be the most important target group to encourage their male partners to participate in community or learning activities, and those who will benefit most from men's engagement with community work, doings and learning.

In the framework of national strategies and the preparation of action plans by various ministries, local and national authorities should support the implementation of legislation that tackles the financial and material vulnerability of older people and those at high risk of poverty. Educational background seems central to quality of life in adulthood and, more specifically, in old age. Lifelong learning programmes provided by educational institutions and (informal) learning programmes should tackle these complex problems not only with educational means, but also with community activities and programmes not necessarily dealing with education, but with greater focus on socialising, mutuality and community (with intergenerational programmes and exchange, creativity, etc.).

Sensibility for gender capital should be developed within organisations dealing with older adults as well as sensibility for the very understanding of the heterogeneity of older adults. Gender should be recognised as plural, relational, multidimensional, and deeply contextual (Johnson \& Repta, 2012), while the heterogeneity of diverse needs, possibilities, capabilities, interests, lifestyles, motivations, experiencing ageing, dealing with ageing, (gender-related) health issues and risks, etc. should be observed. Hegemonic measures can leave many men, particularly those who are disadvantaged and unemployed or who are older, marginalised, under resourced and impact negatively on their mental and physical health status (Foley, 2018, pp. 30-31). Therefore, hegemonic masculinities should be disclosed through public discussion, through education and learning, health promotion and other community programmes - with the consciousness that this issue concerns all generations and all genders.

To go beyond age-segregated communities, older adults should establish more permanent, comprehensive and intergenerational systems of mutual and other forms of assistance in the community, for which intergenerational common spaces should be developed - for exchange, interaction, gathering. Cultural institutions in this regard often represent an important common place if they are open to the community. Institutions of various natures that organise activities for older adults should be aware that the participation of women and men is driven by different factors (and should understand those factors). Activities that are friendly to men and women should exist and social spaces familiar to women and/or men should be nurtured and encouraged. The key is not in organising men-only activities but in the diversity of learning opportunities so that men and women 
can choose the ones they like the most. If a men-only activity is suggested or developed by older men themselves, it should be recognised, valued, supported and accepted with the recognition of a clear need for men's spaces, men's activities, and men's socialisation that can empower older men in their later life.

The evaluation of education and learning opportunities available to older adults should be done in the context of municipalities, considering the possibilities of all institutions and making better use of existing resources. New activities or new institutions should be created only after a global evaluation of the resources/education on offer, taking into consideration the needs of the older population. Male-oriented community programmes have the potential to help men maintain meaningful connections to the activities and roles that they developed throughout their lifetime. They proved to be important for their identity, wellbeing and mental health. The Men's Shed movement as one of the most recognised practices of male-oriented community programmes and its achievements should be widely promoted and (financially) supported.

More generally, local communities should develop more democratic and participatory processes for the involvement of older adults in consultation and other practices that would enable them to contribute to the community and would not need to happen separately or be segregated from the rest of society. Institutions of various natures, worried about the well-being and quality of life of older adults, should build stronger and wider partnerships, including the security and health services.

\section{CONCLUSION}

The aim of this project was to introduce community workers and NGO stakeholders to strategies on how to improve the participation of men aged 60 years or more in the local community and, in particular, how to encourage men's socialisation, informal learning, inclusion and engagement in organisations which are not primarily meant for education and learning in the third and fourth life stages. Therefore, all materials prepared by the project partners suggest how to develop bottom-up strategies for community activities targeting older adults and direction for networking community organisations. Besides this, the project tries to raise public awareness of the social isolation of men aged 60 years or more; build the capacity of national and local institutions/organisations to address the (self-)marginalisation and poor health of older men through social innovations and alternative approaches fostering community learning, doing and socialising.

However, all the project partners faced huge obstacles that cannot be resolved with lifelong learning and active ageing strategies or policies. The financial and material vulnerability of older adults, the high risk of poverty, spatial exclusion, unequal access to health and other institutions, mobility, the need for labour, the social and political participation of older adults (also men aged 60 years or more), among others, are problems that go far beyond the scope of civil society and NGOs dealing with older adults. They should be solved by central government and national policy, in some part also by 
local authorities. But as presented in this article, particularly the suggestions and recommendations in the last section, there are also numerous obstacles that can be solved by civil society and by NGOs. Innovative, more democratic, participative, informal and bottom-up approaches are needed, ones able to consider and re-arrange their spaces, programmes and attitudes towards older adults and consider gendered needs, problems and experiences.

Despite the fact that our project specifically addressed the participation of men aged 60 years or more in the community, some issues and recommendations from this article apply to all genders and in some cases even more to women than to men (e.g. the material deprivation of women vs. men in all countries observed). The purpose of the project was not to exclude women but to research in-depth the local gender-specific issues connected to ageing and shed a light on a group which has so far not been regarded as marginalised or deprivileged except in very few countries (Australia, Canada, Ireland). Equally, the main findings and recommendations from our research study do not propose men-only activities or segregated spaces for men. In fact, interviewees from all partner countries suggested the opposite: that the existent spaces, programmes of learning, action, and creation and meetings of older adults be connected, contextualised (in terms of space, content, activity, openness), and entwined in a community of intergenerational cooperation, where older adults will feel welcome, accepted, needed, respected and equal, and where they will be able to create and make things that they enjoy (including working with their hands and physical work). They might simply hang out and do nothing, as freely as free people do, and belong to the community as old guys, not as consumers or somebody who has to be thought about something by a younger professional in a classroom.

\section{REFERENCES}

Anderson, E. (2009). Inclusive masculinity: The changing nature of masculinities. New York: Routledge.

Barefoot, J. C., Mortensen, E. L., Helms, M. J., Avlund, K., \& Schroll, M. (2001). A longitudinal study of gender differences in depressive symptoms from age 50 to 80. Psychology and Aging, 16(2), $342-345$.

Boveda, I., \& Metz, A. J. (2016). Predicting end-of-career transition for baby boomers nearing retirement age. Career Development Quarterly, 64(2), 153-168.

Bridges, T., \& Pascoe, C. J. (2014). Hybrid masculinities: New directions in the sociology of men and masculinities. Sociology Compass, 8, 246-258.

Canneto, S. (2015). Suicide: Why are older men so vulnerable? Men and Masculinities, 20(2), 49-70.

Carragher, L., \& Golding, B. (2015). Older men as learners: Irish men's sheds as an intervention. Adult Education Quarterly, 65(2), 152-168.

Connell, R. W., \& Messerschmidt, J. W. (2005). Hegemonic masculinity: Rethinking the concept. Gender \& Society, 19, 829-859.

Courtenay, W. H. (2000). Construction of masculinity and their influence on men's well-being: A theory of gender and health. Social Science and Medicine, 50, 1385-1401.

Creighton, G., \& Oliffe, J. L. (2010). Theorising masculinities and men's health: A brief history with a view to practice. Health Sociology Review, 19, 409-418. 
Dettinger, E., \& Clarkberg, M. (2002). Informal caregiving and retirement timing among men and women: Gender and caregiving relationships in late midlife. Journal of Family Issues, 23(7), 857-879.

Eurostat (2017). Adult participation in learning by gender (\%). Retrieved from http://ec.europa.eu/eurostat/tgm/table.do?tab=table \&init=1\&plugin=1\&lang.

Fleming, A. A. (1999). Older men in contemporary discourses on ageing: Absent bodies and invisible lives. Nursing Inquiry, 6(1), 3-8.

Filipp, S. H., \& Olbrich, E. (1986). Human development across the life span: Overview and highlights of the psychological perspective. In A. B. Sorensen, F. E. Weinert, \& L. R. Sherrod (Eds.), Human development and the life course: Multi-disciplinary perspective (pp. 343-375). Hillsdale: Lawrence Eribaum.

Foley, A. (2018). Masculine gendered spces. Studies in Adult Education and Learning, 24(3), 29-38.

Formosa, M., Galea R. C., \& Bonello, R. F. (2014). Older men learning through religious and political affiliation: Case studies from Malta. Andragoška spoznanja, 20(3), 57-69.

Fragoso, A., Ricardo, R., Tavares, N., \& Coelho, A. (2014). Shoulder to shoulder? Masculinities and informal learning in later life. Andragoška spoznanja, 20(3), 27-39.

Franzosi, R. (Ed.) (2008). Content Analysis. Methodological Playing Field. Los Angeles: SAGE.

Gregorčič, M. (2017). Participacija starejših odraslih v praksah skupnosti in v skupnosti prakse. Andragoška spoznanja, 23(3), 35-53.

Glaser, B. G. (1978). Theoretical Sensitivity. The Sociology Press: Mill Valley.

Glaser, B. G. (1992). Basics of Grounded Theory Analysis: Emergence vs Forcing. The Sociology Press: Mill Valley.

Gleibs, I. H., Haslam, C., Jones, J. M., Haslam, S. A., McNeill, J., \& Connolly, H. (2011). No country for old men? The role of a 'Gentlemen's Club' in promoting social engagement and psychological well-being in residential care. Aging and Mental Health, 15(4), 456-466.

Golden, J., Conroy, R. M., \& Lawlor, B. A. (2009). Social support network structure in older people: Underlying dimensions and association with psychological and physical health. Psychology, Health \& Medicine, 14(3), 280-9.

Golding, B. (2011a). Older men's wellbeing through community participation in Australia. International Journal of Men's Health, 10(1), 26-44.

Golding, B. (2011b). Taking charge at any age: Learning and wellbeing by older men through community organisations in Australia. Adult Learner 2011: The Irish Journal of Adult and Community Education. Retrieved from https://files.eric.ed.gov/fulltext/EJ954304.pdf.

Golding, B. (Ed.) (2015). The men's shed movement: The company of men. Champaign: Common Ground Publishing.

Golding, B., \& Foley, A. (2017). Men and boys: Sharing the skills across generations. Journal of Intergenerational Relationships, 15(1), 52-63.

Golding, B., Mark, R., \& Foley, A. (2014). Men's turn to learn? Discussion and conclusion. In B. Golding, R. Mark \& A. Foley (Eds.), Men Learning Through Life (pp. 244-259). Leicester: NIACE.

Goth, U. S., \& Småland, E. (2014). The role of civic engagement for men's health and well-being in Norway - A contribution to public Health. International Journal of Environmental Research and Public Health, 11, 6375-6387.

Gottlieb B. H., \& Gillespie A. A. (2008). Volunteerism, health, and civic engagement among older adults. Canadian Journal on Aging, 27(4), 399-406.

Gregorčič, M. (2017). Participacija starejših odraslih v praksah skupnosti in v skupnosti prakse. Andragoška spoznanja, 23(3), 35-53.

Hanlon, N. (2012). Masculinities, care and equality: Identity and nurture in men's lives. Basingstoke: Palgrave Macmillan. 
Huppatz, K., \& Goodwin, S. (2013). Masculinised jobs, feminised jobs and men's 'gender capital' experiences: Understanding occupational segregation in Australia. Journal of Sociology, 49(2/3), 291-308.

Jelenc Krašovec, S., \& Gregorčič, M. (2017). Intergenerational exchange of knowledge, skills, values and practices between self-organized active citizens in Maribor, Slovenia. Australian Journal of Adult Learning, 57(3), 401-420.

Jelenc Krašovec, S., \& Radovan, M. (Eds.) (2014). Older men learning in the community: European snapshots. Ljubljana: Ljubljana University Press, Faculty of Arts.

Johnson, J. L., \& Repta, R. (2012). Sex and gender: Beyond the binaries. In J. L. Oliffe \& L. Greaves (Eds.), Designing and conducting gender, sex and health research (pp. 17-37). Thousand Oaks: Sage.

Krajnc, A. (2016). Starejši se učimo. Izobraževanje starejših v teoriji in praksi. Ljubljana: SUTŽO.

Mackenzie, C. S., Roger, K., Robertson, S., Oliffe, J. L., Nurmi, M. A., \& Urquhart, J. (2017). Counter and Complicit Masculine Discourse Among Men's Shed Members. American Journal of Men's Health, 11(4) 1224-1236.

Mark, R., \& Golding, B. (2012). Fostering social policies for engagement of older men in learning and improvement of their health and wellbeing. International Journal of Education and Ageing, 2(3), 221-236.

McGivney, V. (1999). Excluded men: Men who are missing from education and training. Leicester: NIACE.

McGivney, V. (2004). Men earn, women learn: Bridging the gender divide in education and training. Leicester: NIACE.

Merriam, S. B., \& Kee, Y. (2014). Promoting community wellbeing: The case of lifelong learning for older adults. Adult Education Quarterly, 64(2), 128-144.

Oliffe, J. L., \& Han, C. S. E. (2014). Beyond workers' compensations: Men's mental health in and out of work. American Journal of Mental Health, 8(1), 45-53.

Owens, T. (2000). Men on the move: A study of barriers to male participation in education and training initiatives. Dublin: AONTAS.

Paúl, C., \& Ribeiro, O. (2009). Predicting loneliness in old people living in the community. Reviews in Clinical Gerontology, 19, 1-8.

Peak, T., \& Gast A. J. (2014). Aging men's health-related behaviors. SAGE Open, 4(4), 1-10.

Reynolds, K. A., Mackenzie, C. S., Medved, M., \& Roger, K. (2015). The experiences of older male adults throughout their environment in community programme for men. Aging \& Society, 35, 531-551.

Ribeiro, O., Paúl, C., \& Nogueira, C. (2007). Real men, real husbands: Caregiving and masculinities in later life. Journal of Aging Studies, 21, 302-313.

Rosenthal, G. (1993). Reconstruction of life stories. Principles of selection in generating stories narrative biographical interviews. Narrative Study of Lives, 1(1), 59-91.

Schmidt-Hertha, B., \& Rees, S. L. (2017). Transition to retirement - Learning to redesign one's lifestyle. Research on Ageing and Social Policy, 5(1), 32-56.

Schreir, M. (2012). Qualitative content analysis in practice. London: Sage.

Schuller, T., \& Desjardins, R. (2007). Understanding the social outcomes of learning. Paris: OECD.

Schütze, F. (2012). Trajektorie cierpienia jako przedmiot badań socjologii interpretatywnej. In K. Kaźmierska (Ed.), Metoda biograficzna w socjologii. Antologia tekstów (pp. 415-458). Kraków: Zakład Wydawniczy Nomos.

Tett, L., \& Maclachlan, K. (2007). Adult literacy and numeracy, social capital, learner identities and self-confidence. Studies in the Education of Adults, 39, 173-167. 
Thompson, E. H. (2007). Older men as invisible men in contemporary society. In B. A. Arrighi (Ed.), Understanding inequality: The intersection of racelethnicity, class, and gender (pp. 289-298). Oxford: Rowman and Littlefield.

Vandervoort, D. (2012). Social Isolation and Gender. Current Psychology, 19(3), 229-236.

Wang, H.-X., Karp, A., Winblad, B., \& Fratiglioni, L. (2002). Late-life engagement in social and leisure activities is associated with a decreased risk of dementia: A longitudinal study from the Kungsholmen Project. American Journal of Epidemiology, 155(12), 1081-1087.

Wijngaarden, E. van, Leget, C., \& Goossensen, A. (2015). Ready to give up on life: The lived experience of elderly people who feel life is completed and no longer worth living. Social Science \& Medicine, $138,257-264$.

Williamson, T. (2011). Grouchy old men? Promoting older men's mental health and emotional wellbeing. Working with Older People, 15, 64-76. 